\title{
Morphological variations and phylogenetic analysis of Oryzias nigrimas Kottelat, 1990 (Rice fish) from Lake Poso, Central Sulawesi, Indonesia
}

\author{
NOVALINA SERDIATI ${ }^{1, \bullet}$, DIANA ARFIATI ${ }^{2}$, MAHENO SRI WIDODO ${ }^{2}$, TRI JOKO LELONO ${ }^{2}$, \\ SAMLIOK NDOBE ${ }^{1}$, RUDY SARANGA ${ }^{3}$ \\ ${ }^{1}$ Faculty of Animal Husbandry and Fisheries, Universitas Tadulako. Jl. Soekarno-Hatta Km. 9, Tondo, Mantikulore, Palu 94148, Central Sulawesi, \\ Indonesia. Tel.: +62-451-422611, Fax.: +62-451-422-844, ^email: novalinaserdiati@untad.ac.id \\ ${ }^{2}$ Faculty of Fisheries and Marine Science, Universitas Brawijaya. Jl. Veteran No.16, Malang 65145, East Java, Indonesia \\ ${ }^{3}$ Department of Fishing Technique, Politeknik Kelautan dan Perikanan Bitung. Jl. Tandurusa, Bitung 95526, North Sulawesi, Indonesia
}

Manuscript received: 26 December 2019. Revision accepted: 5 February 2020.

\begin{abstract}
Serdiati N, Arfiati D, Widodo MS, Lelono TJ, Ndobe S, Saranga R. 2020. Morphological variations and phylogenetic analysis of Oryzias nigrimas Kottelat, 1990 (Rice fish) from Lake Poso, Central Sulawesi, Indonesia. Biodiversitas 21: 882-888. Rice fish (Oryzias nigrimas Kottelat, 1990) is a well-studied species endemic to Lake Poso, Sulawesi and identified as scarce. This study aims to identify the Rice fish of Lake Poso, Central Sulawesi based on morphological characters (15 morphometric characters and 5 meristic counts) and phylogenetic analysis using maximum-likelihood (ML) method based on mtDNA, CO1 gene. Based on the morphological analysis, it was showed that the meristic counts show significantly different only on the lateral line scale. However, the morphometric measurements show significantly different characteristics on postorbital distance, body depth, and length of jaw. Our phylogenetic analysis also showed that our samples are indeed a species of $O$. nigrimas. We suggest that the endemicity of this Rice fish on Lake Poso is greatly influenced by the well-maintained genetic structure of the population.
\end{abstract}

Keywords: Indonesia, Lake Poso, morphological variations, Oryzizas nigrimas, phylogenetic analysis

\section{INTRODUCTION}

Rice fishes are an important freshwater fish group, are significant species that were used as a model organism and well-studied species (Parenti 2008; Lin et al. 2016; Shima and Matani 2004; Wawrowski et al. 2011). Rice fishes belong to the Adrianichtyidae family are distributed and considered native to Southeast Asia, Japan, India and as far as Timor (Magtoon and Termvidchakorn, 2009). There are about 36 valid species, and some are considered rare and few of those were predicted to be extinct in the future (Mandagi et al. 2018). Recently, two genera of Rice fishes were distinguished by the genera of Oryzias and Adrianichthys (Mandagi et al. 2018). Some species of Rice fish especially the genus Oryzias are known to be endemic to Indonesia (Inoue and Takei 2003). A recent study showed that Oryzias fishes are divided into three species groups which are the latipes, javanicus, and the celebensis group (Takehana et al. 2005) which contain one of the endemic species in Celebensis (Sulawesi) i.e Oryzias nigrimas Kottelat, 1990 found on Lake Poso, Central Sulawesi of Indonesia.

Information on how the $O$. nigrimas end up in Lake Poso, and whether the speciation process takes place by the distinction of a population group are yet to be confirmed and despite the widely used of this species, their phylogenetic relationship of these genera is also poorly understood (Takehana et al. 2005). There are two techniques was officially used to explain the speciation process and to reconstruct the phylogenetic tree namely morphological approach and molecular approach. The morphological characteristics of fish such as body shape, color pattern and number of scales can be used as preliminary methods to distinguish the species (Ikpeme et al. 2017). However, these methods are difficult and considered subjective to sever the species among the same genus. Therefore, the molecular approach is recently used to strengthen morphological approach by using DNA barcoding.

Molecular approach in fish was developed based on its rapid and accurate to identify the species using universal primers. Many fishes were identified and characterized by using this molecular approach including genus of Labiobarbus (Panprommin et al. 2019) and Taiwan Fish (Bingpeng et al. 2018). Furthermore, molecular approach also has been used to determine biodiversity in several natural waters. Mitochondrial DNA that generally used as DNA barcoding is cytochrome subunit I (COI). COI gene is a highly conserved region that has been used across all levels of an organism to identify species, differing by only a few sequences (variable sites) (Folmer et al. 1994). COI sequences can be used as primary barcodes to classify and identify both freshwater fish and marine fish (Viswambharan et al. 2015; Bingpeng et al. 2018).

The used of both morphological characteristics and phylogenetic analysis are a synergistic combination to determine the identity of these freshwater fish by the comparison between phylogeny trees and morphometric and meristic characters (Kim et al. 2010; Marzouk et al. 2016). Hence, in this study, we assess the morphometric 
and meristic characters of $O$. nigrimas from several sites in Lake Poso, Central Sulawesi, Indonesia, as well as molecular character of cytochrome subunit I (CO1) for phylogenetic reconstruction. We also discuss the reliability of our morphological methods that are used for analyzing the $O$. nigrimas and compare our genetic data to the available DNA sequence.

\section{MATERIALS AND METHODS}

\section{Field location and samples collecting}

Sampling was carried out in the 3 sites, namely Watudilana, Tolambo, Taipa of Lake Poso, Central Sulawesi, Indonesia. As much as 15 samples of $O$. nigrimas (Rice Fish) were collected from each sampling site and preserved for morphological analysis and DNA extraction purposes. The preferred sites were marked its coordinates using GPS and projected as shown in Figure 1.

\section{Morphometrics and meristic analysis}

As much as 15 samples in each population sites were measured using morphological analysis. The morphological analysis consists of 15 morphometric measurements and 5 meristic counts following to Holden and Raitt (1974). Morphometric characters include characteristics as follows: Standard length (SL), total length (TL), head length (HL), Preorbital Distance (PRD), Eye diameter (ED), Post orbital Distance (POD), Predorsal distance (PD), pre-pelvic distance (PPED), pre-pectoral distance (PPD), pectoral fin length (PFL), Body depth (BD), dorsal fin length (DFL), Anal fin length (AFL), length of jaw (PRg), and Tail stem height (Figure 2). Meristic characters include the number of scales along the lateral line, the number of dorsal, ventral, pectoral and anal fin fingers. Data were analyzed using Oneway ANOVA and further tested using Duncan Test on SPSS 13 for Windows.

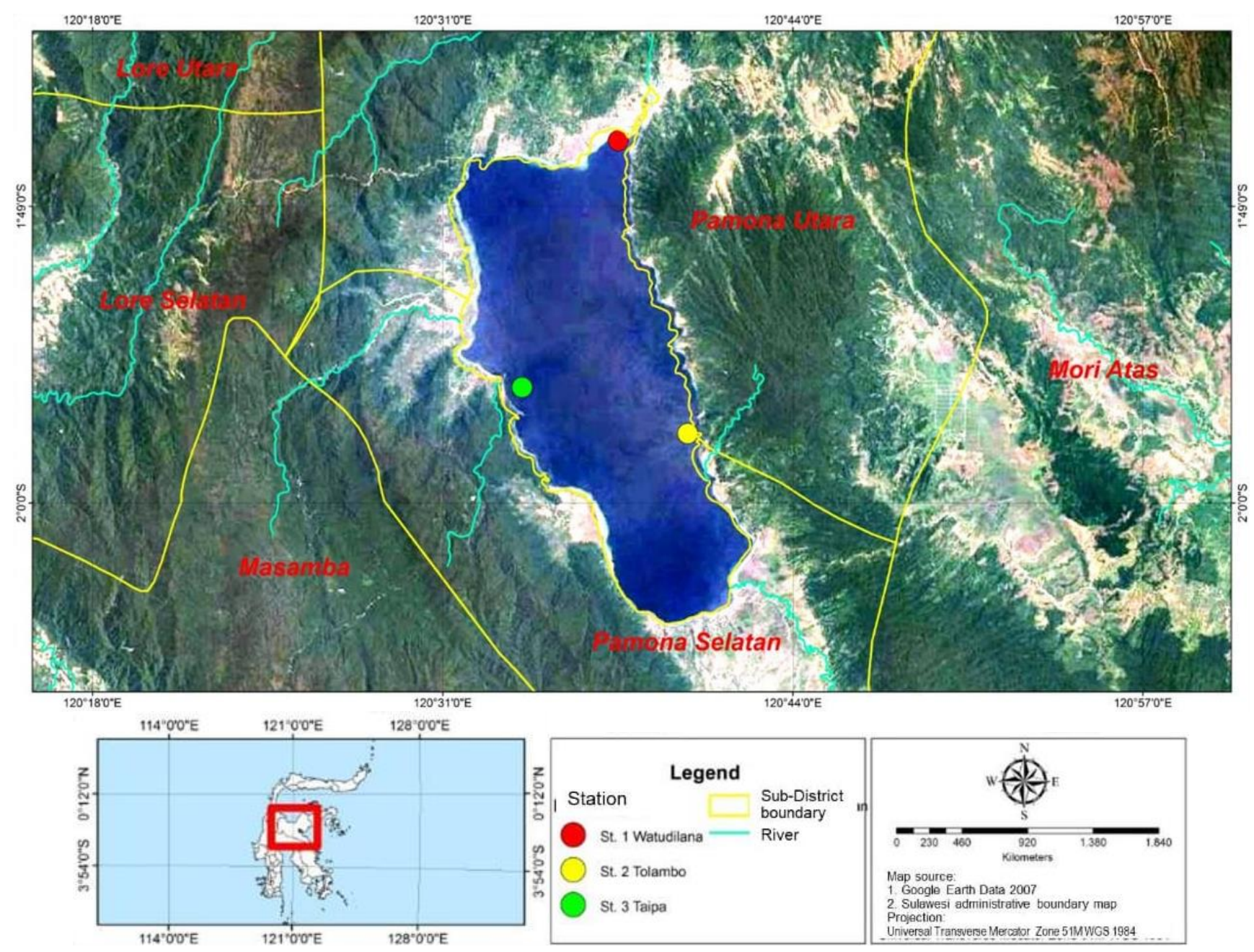

Figure 1. Sample collection of Rice fish (Oryzias nigrimas) location on Lake Poso, Central Sulawesi, Indonesia, the colored dots indicated the specific sampling sites (Notes: red: Watudilana, yellow: Tolambo, green: Taipa, yellow line: district boundaries, blue line: river flows) 


\section{DNA extraction, amplification, and sequencing}

The total genomic DNA was extracted from part of the caudal fin from each of fish. DNA isolation was carried out using the GENEAID kit (Tissomic DNA Mini.). The DNA Isolation steps were following its manufacturer protocol for animal tissue. DNA Amplification was performed with PCR Thermocycler (Bio-Rad) using two CO1 primers. We amplified and sequenced the mitochondrial DNA specifically the CO1 gene using following primers: BCL: 5'-TCA ACY AAT CAY AAA GAT ATY GGC AC-3 'and Fish BCH: 5'-ACT TCY GGG TGR CCR AAR AAT CA3'. PCR reaction was carried out in total volume $50 \mu \mathrm{l}$ consisting of $2 \mu \mathrm{l}$ DNA $(100 \mathrm{ng} / \mu \mathrm{l}), 2.5 \mu \mathrm{l}$; Forward Primer $(10 \mu \mathrm{M}) ; 2.5 \mu \mathrm{l}$ Reverse Primer $(10 \mu \mathrm{M}), 18 \mu \mathrm{lddH} 2 \mathrm{O}$ and $25 \mu \mathrm{l}$ Go Taq Green (Promega). the amplifications were carried out under the following condition: 1 cycle of predenaturation at $94{ }^{\circ} \mathrm{C}$ for 5 minutes, followed by 40 cycles of denaturation at $94{ }^{\circ} \mathrm{C}$ for 30 seconds, annealing at $50{ }^{\circ} \mathrm{C}$ for 30 seconds, extension at $72^{\circ} \mathrm{C}$ for 45 seconds, subsequently followed by a final extension at $72{ }^{\circ} \mathrm{C}$ for 7 minutes. The final samples were sequenced using the BigDye ${ }^{\circledR}$ Terminator v3.1 (Applied Biosystem) First base Malaysia.

\section{Sequence alignment and phylogenetic analysis}

The sequenced of the mtDNA gene COI (ab1 format) were analyzed using Sequence Scanner (Applied Biosystem) and converted into fasta format using CLUSTAL X. The sequences were aligned in MEGA X version (Kumar et al. 2018) and Bioedit (Hall, 1999) software, with additional sequences from NCBI (Table 1). Genetic distance was analyzed by pair-distance using MEGA X (Kumar et al. 2018). The phylogenetic relationships were analyzed by the maximum-likelihood (ML) method using MEGA X (Kumar et al. 2018). The analyses were performed based on the Kimura-2 parameter distance (Kimura, 1980). To evaluate the robustness of internal branches of the trees, 1000 bootstrap replication was executed, using the heuristic algorithm.

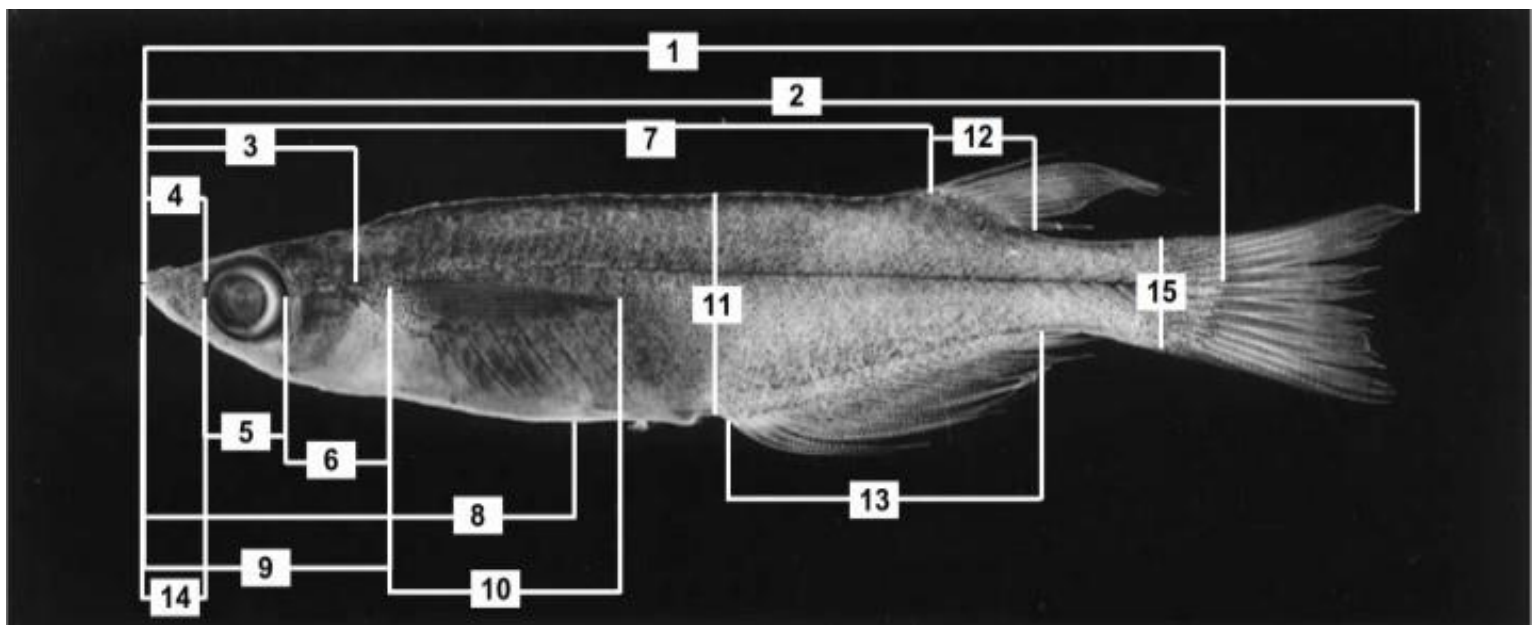

Figure 2. A total of 15 morphometrical characters of Oryzias nigrimas that are measured, notation and abbreviations as follows: 1. Standard length (SL), 2. total length (TL), 3. head length (HL), 4. Preorbital Distance (PRD), 5. Eye diameter (ED) 6. Post orbital Distance (POD), 7. Predorsal distance (PD), 8. pre-pelvic distance (PPED), 9. pre-pectoral distance (PPD), 10. pectoral fin length (PFL), 11. Body depth (BD), 12. dorsal fin length (DFL), 13. Anal fin length (AFL), 14. length of jaw (PRg), and 15. Tail stem height.

Table 1. List of Rice Fish Oryzias spp. used in this study.

\begin{tabular}{llll}
\hline Samples & Locality & Accesion & Sources \\
\hline O. nigrimas 1 & Tolambo, Lake Poso, Sulawesi & - & This study \\
O. nigrimas 2 & Watudilana, Lake Poso, Sulawesi & - & This study \\
O. nigrimas 3 & Taipa, Lake Poso, Sulawesi & - & This study \\
O. nigrimas & Aichi, Higashiyama Zoo, Japan & LC153106.1 & Direct submission \\
O. nebulosus & Aichi, Higashiyama Zoo, Japan & LC153098 & Direct submission \\
Oryzias sp. & Aichi, Higashiyama Zoo, Japan & LC153107.1 & Direct submission \\
O. marmoratus & Aichi, Higashiyama Zoo, Japan & LC154797.1 & Direct submission \\
O. sarasinorum & Aichi, Higashiyama Zoo, Japan & LC154798.1 & Direct submission \\
O. matanensis & Aichi, Higashiyama Zoo, Japan & LC153099.1 & Direct submission \\
O. celebensis & Sulawesi and Timor, Japan & JX311942.1 & Parenti et al. 2013 \\
O. woworae & Muna Island, Sulawesi, Japan & JX311940.1 & Parenti et al. 2013 \\
O. asinua & Asinua river, Sulawesi, Japan & JX311929.1 & Parenti et al. 2013 \\
\hline
\end{tabular}




\section{RESULTS AND DISCUSSION}

\section{Meristic count and morphometric measurement analysis of Oryzias nigrimas (Rice fish) from Lake Poso, Central Sulawesi}

The results of the meristics count (Table 2) and morphometrics measurement (Table 3) are shown below. Our analysis showed that meristics counts on the number of dorsal fin ray, ventral fins ray, pectoral fin ray, and anal fin ray are not significantly different to make submission that the species were morphologically different. However, the lateral line scale is significantly different, between the $O$. nigrimas (Rice fish) from Tolambo and Watudilana population. Subsequently, our analyses on morphometric measurement did not show any significant differences in characters except postorbital distance, body depth, and length of jaw. The difference on lateral line scale counts suggests that this character may be influenced by environmental conditions and also both physical and composition of these water (Quilang et al. 2007; Wark et al. 2010).

Measurement of morphometric and meristic characteristics can be used to determine the taxonomic and systematics of fish (Simon et al. 2010). Meristic counts are based on more primitive characters than morphometric measurements and would, therefore, provide stronger evidence for speciation. In addition, species status would only be accepted if there was no overlap in the range of at least one of the investigated meristic characters or morphometric ratios (Fakunmoju et al. 2014). Environmental changes greatly affect the freshwater fish adaptation, that manifested on the changes of morphological features (Braich and Akhter 2015). No significantly different in morphological characteristics of $O$. Nigrimas other than caused by the similarity habitat or environmental factors may also be associated with pronounced differences in resource acquisition and predator escape (Seebacher et al. 2016).

\section{Genetic distance and Phylogenetic analysis of $O$. nigrimas (Rice fish) from Lake Poso, Central Sulawesi}

Based on our genetic distance analyses of $651 \mathrm{bp}$ of CO1 mtDNA genes of $O$. nigrimas (Rice fish) from 3 different sampling sites in Lake Poso, Central Sulawesi, it was shown that our samples have low genetic distance (at a value of 0.005 ) to the $O$. nigrimas (Table 4). It was indicated that the $O$. nigrimas from 3 different sampling sites (Tolambo, Watudilaa, Taipa) from Lake Poso, are identically similar to $O$. nigrimas. It was considered that there was no genetic isolation occur and genetic structure are well maintained to form the single species (Braich and Akhter, 2015) in Lake Poso.

Table 2. Meristic count of Rice fish Oryzias nigrimas from several sites in Lake Poso, Central Sulawesi (Mean \pm SD).

\begin{tabular}{llll}
\hline Meristic count & Watudilana & Tolambo & Taipa \\
\hline Lateral line scale & $19.92^{\mathrm{b}} \pm 2.11(17-23)$ & $18.17^{\mathrm{a}} \pm 1.27(16-21)$ & $18.83^{\mathrm{ab}} \pm 1.27(17-21)$ \\
Dorsal Fin ray & $8.50^{\mathrm{a}} \pm 1.24(7-11)$ & $8.42^{\mathrm{a}} \pm 1.31(7-11)$ & $8.92^{\mathrm{a}} \pm 1.24(7-11)$ \\
Ventral fin ray & $5.08^{\mathrm{a}} \pm 0.90(4-6)$ & $4.83^{\mathrm{a}} \pm 1.03(4-6)$ & $4.92^{\mathrm{a}} \pm 1.00(4-6)$ \\
Pectoral fin ray & $14.33^{\mathrm{a}} \pm 1.78(12-17)$ & $14.33^{\mathrm{a}} \pm 1.67(12-17)$ & $14.17^{\mathrm{a}} \pm 1.64(12-16)$ \\
Anal fin ray & $23.17^{\mathrm{a}} \pm 1.40(22-25)$ & $22.75^{\mathrm{a}} \pm 0.87(22-24)$ & $22.75^{\mathrm{a}} \pm 0.62(22-23)$ \\
\hline
\end{tabular}

Note: Each variable using a $5 \%$ significance with the same superscript letter is not significantly different.

Table 3. Measurement of 15 morphometric characters of Rice fish Oryzias nigrimas from several sites in Lake Poso, Central Sulawesi $(\mathrm{Mean} \pm \mathrm{SD})$

\begin{tabular}{llll}
\hline Morphometric character & Watudilana & Tolambo & Taipa \\
\hline Total Length & $51.36^{\mathrm{a}} \pm 3.45$ & $51.03^{\mathrm{a}} \pm 3.00$ & $52.51^{\mathrm{a}} \pm 2.14$ \\
Standard Length & $44.30^{\mathrm{a}} \pm 4.88$ & $40.96^{\mathrm{a}} \pm 3.70$ & $43.93^{\mathrm{a}} \pm 4.04$ \\
Head length & $11.80^{\mathrm{a}} \pm 1.72$ & $12.17^{\mathrm{a}} \pm 0.98$ & $12.31^{\mathrm{a}} \pm 0.97$ \\
Preorbital Distance & $2.93^{\mathrm{a}} \pm 0.45$ & $2.96^{\mathrm{a}} \pm 0.47$ & $2.77^{\mathrm{a}} \pm 0.41$ \\
Eye diameter & $3.88^{\mathrm{a}} \pm 0.71$ & $3.83^{\mathrm{a}} \pm 0.67$ & $4.15^{\mathrm{a}} \pm 0.58$ \\
Post orbital distance & $3.03^{\mathrm{a}^{\mathrm{a}} \pm 0.57}$ & $2.79^{\mathrm{a}} \pm 0.59$ & $3.37^{\mathrm{b}} \pm 0.47$ \\
Predorsal distance & $32.75^{\mathrm{a}} \pm 5.15$ & $30.24^{\mathrm{a}} \pm 4.07$ & $32.61^{\mathrm{a}} \pm 3.46$ \\
Pre-pelvic distance & $18.35^{\mathrm{a}} \pm 4.55$ & $17.24^{\mathrm{a}} \pm 3.38$ & $19.27^{\mathrm{a}} \pm 2.38$ \\
Pre-pectoral distance & $12.59^{\mathrm{a}} \pm 1.75$ & $13.19^{\mathrm{a}} \pm 0.92$ & $13.25^{\mathrm{a}} \pm 0.75$ \\
Pectoral fin length & $3.25^{\mathrm{a}} \pm 0.53$ & $3.22^{\mathrm{a}} \pm 0.80$ & $3.35^{\mathrm{a}} \pm 0.67$ \\
Body depth & $4.98^{\mathrm{a}} \pm 0.97$ & $4.36^{\mathrm{a}} \pm 1.00$ & $5.25^{\mathrm{b}} \pm 1.04$ \\
Dorsal fin length & $13.38^{\mathrm{a}} \pm 1.26$ & $13.61^{\mathrm{a}} \pm 1.31$ & $13.87^{\mathrm{a}} \pm 1.16$ \\
Anal fin length & $5.63^{\mathrm{a}} \pm 1.15$ & $5.46^{\mathrm{a}} \pm 1.18$ & $6.17^{\mathrm{a}} \pm 1.56$ \\
Length of jaw & $8.21^{\mathrm{b} \pm 1.78}$ & $6.64^{\mathrm{a}} \pm 1.30$ & $7.79^{\mathrm{ab}} \pm 1.15$ \\
Height of tail stem & $3.37^{\mathrm{a}} \pm 0.80$ & $3.45^{\mathrm{a}} \pm 0.54$ & $3.24^{\mathrm{a}} \pm 0.51$ \\
\hline
\end{tabular}

Note: Each variable using a 5\% significance with the same superscript letter is not significantly different. 
This condition is will threaten the sustainability of $O$. nigrimas in the future since genetic diversity is the only way to predict whether $O$. nigrimas can adapt to future conditions. On the other hand, reduced genetic diversity may cause decreased population viability and increased extinction, especially for populations faced with stressful environmental conditions (Martinez et al. 2018). The lower genetic diversity of freshwater fish relative to marine fish also reported by DeWoody and Avise (2000) and Martinet et al (2018). Large genetic diversity of marine species suggests that marine fishes may inhabit more productive environments that allow for higher carrying capacities. In addition, larger population sizes also suggest that marine environments may be more stable and thus may be less sensitive to or experience smaller amounts of genetic drift (April et al. 2012).

Our phylogenetic analysis based on successfully amplified CO1 genes (651 base pairs) also showed $O$. nigrimas (Rice fish) from 3 different sampling sites in Lake
Poso, Central Sulawesi are nested within the same clade of another $O$. nigrimas (Figure 3) with a well-supported bootstrap on the nodes (maximum-likelihood bootstrap value: 94). The bootstrap value indicates the consistency of data, manifested in percentages. Low values mean that the alignment gives a different tree topology on each sampling. The considered well- supported bootstrap value for maximum likelihood analysis is at $>75 \%$ (Yang, 1994). However, based on the observations of our alignment, it was shown that there were variations in several sites, yet inadequate to differentiate the samples. According to Kres and Erickson (2012), the CO1 gene has the capability to distinguish the taxa up to species level because of the highly conserved and variations of the region. These variations of nucleotides can be used as a character that distinguishes the species. The high variation of nucleotides among a sequence of samples is an effective tool to identify Rice fish species (Zhang and Hanner 2012).

Table 4. Genetic distances of Oryzias nigrimas from Lake Poso, Central Sulawesi and additional sample Oryzias spp. from the Gene bank database inferred by $\mathrm{p}$-distance.

\begin{tabular}{|c|c|c|c|c|c|c|c|c|c|c|c|c|}
\hline & 1 & 2 & 3 & 4 & 5 & 6 & 7 & 8 & 9 & 10 & 11 & 12 \\
\hline O. nigrimas_Tolambo & 0.000 & & & & & & & & & & & \\
\hline O. nigrimas 2_Watudilana & 0.000 & 0.000 & & & & & & & & & & \\
\hline O. nigrimas 3_Taipa & 0.000 & 0.000 & 0.000 & & & & & & & & & \\
\hline O. nigrimas_Japan & 0.005 & 0.005 & 0.005 & 0.000 & & & & & & & & \\
\hline O. nebulosus_Japan & 0.027 & 0.027 & 0.027 & 0.025 & 0.000 & & & & & & & \\
\hline Oryzias sp._Japan & 0.063 & 0.063 & 0.063 & 0.065 & 0.073 & 0.000 & & & & & & \\
\hline O. marmoratus_Japan & 0.103 & 0.103 & 0.103 & 0.105 & 0.107 & 0.107 & 0.000 & & & & & \\
\hline O. sarasinorum_Japan & 0.113 & 0.113 & 0.113 & 0.107 & 0.105 & 0.122 & 0.112 & 0.000 & & & & \\
\hline O. matanensis_Japan & 0.125 & 0.125 & 0.125 & 0.123 & 0.121 & 0.112 & 0.072 & 0.107 & 0.000 & & & \\
\hline O. celebensis_Sulawesi & 0.129 & 0.129 & 0.129 & 0.125 & 0.121 & 0.127 & 0.140 & 0.118 & 0.144 & 0.000 & & \\
\hline O. woworae_Muna & 0.127 & 0.127 & 0.127 & 0.125 & 0.133 & 0.131 & 0.129 & 0.122 & 0.132 & 0.137 & 0.000 & \\
\hline O. asinua_Sulawesi & 0.127 & 0.127 & 0.127 & 0.125 & 0.133 & 0.128 & 0.134 & 0.125 & 0.140 & 0.137 & 0.009 & 0.000 \\
\hline
\end{tabular}
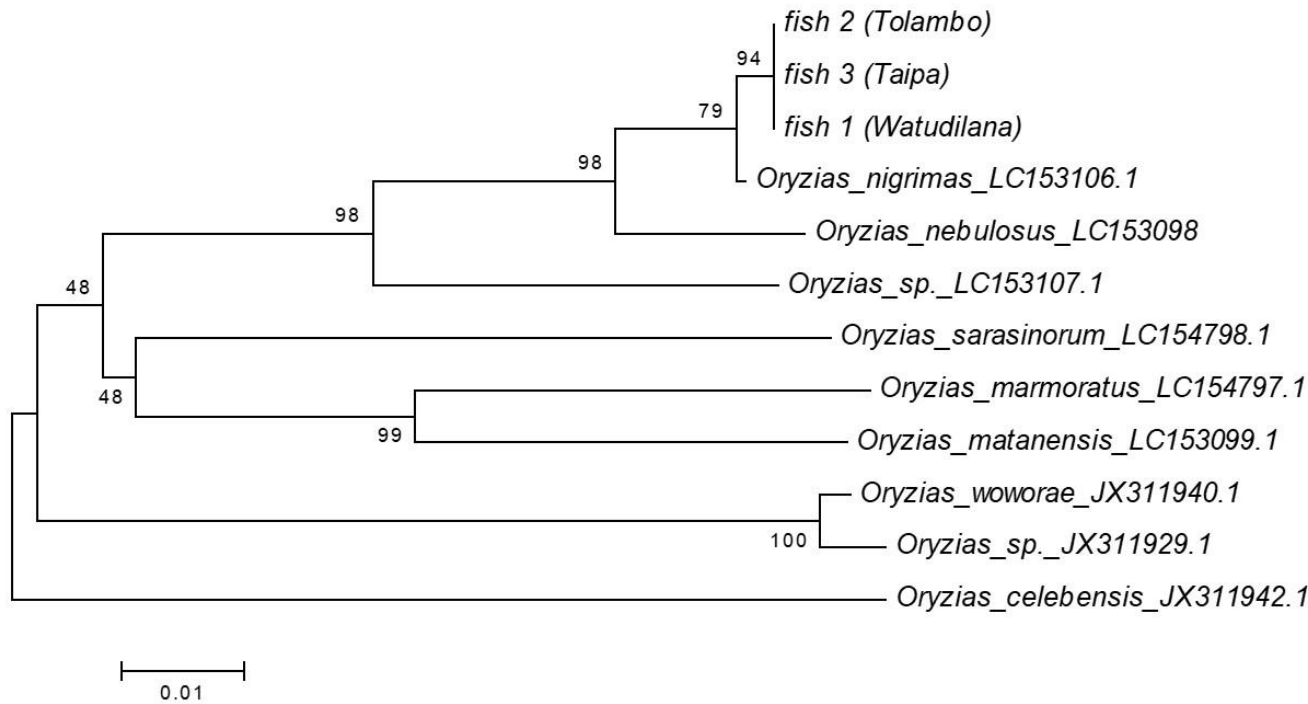

Figure 3. Phylogenetic trees of Oryzias nigrimas (Rice fish) from Lake Poso, Central Sulawesi based on maximum-likelihood (ML) methods 
Further, a polymorphism that occurs in DNA sequences of the $\mathrm{CO} 1$ gene may also be used as tools in distinguishing and identify the species in a population (Liu et al. 2017; Wang et al. 2011). The presence of polymorphism in Rice fish serves as a marker for the other Rice fish of Lake Poso other populations. The endemicity of this Rice fish will greatly be influenced by well-maintained population, whether it was reduced or lost due to natural or external causes

To conclude, our morphological analysis showed that the meristic counts show significantly different only on the lateral line scale. However, the morphometric measurements show significantly different characteristics on postorbital distance, body depth, and length of jaw. Our phylogenetic analysis also resolved that the samples that were analyzed are indeed an endemic species of $O$. nigrimas. We suggest that the endemicity of this Rice fish on Lake Poso is greatly influenced by the well-maintained genetic structure of the population. Future studies examining the genetic diversity in $O$. nigrimas should examine using alternative markers. Application of nextgeneration sequencing may help to inquire into whether patterns of genome-wide genetic diversity in $O$. nigrimas show similar relationships with our study. Finally, we expect there are future studies that pay attention to well-resolved phylogenies and thereby remove additional noise from the analysis.

\section{ACKNOWLEDGEMENTS}

Acknowledgments are expressed in a brief; all sources of institutional, private and corporate financial support for the work must be fully acknowledged, and any potential conflicts of interest are noted.

\section{REFERENCES}

April J, Hanner RH, Dion-Côté AM, Bernatchez L. 2012. Glacial cycles as an allopatric speciation pump in north-eastern American freshwater fishes. Mol Ecol 22: 409-422.

Braich OS, Akhter S. 2015. Morphometric characters and meristic counts of a fish, Crossocheilus latius latius (Hamilton-Buchanan) from Ranjit Sagar Wetland, India. Int J Fish Aquac Stud 2 (5): 260-265.

Bingpeng X, Heshan L, Zhilan Z, Chunguang W, Yanguo W, Jianjun W. 2018. DNA barcoding for identification of fish species in the Taiwan Strait. PLoS One 13 (6): e0198109. DOI 10.1371/journal.pone.0198109.

DeWoody JA, Avise JC. 2000. Microsatellite variation in marine, freshwater and anadromous fishes compared with other animals. J Fish Biol 56: 461-473.

Folmer O, Black M, Hoeh W, Lutz R, Vrijenhoek R. 1994. DNA primers for amplification of mitochondrial cytochrome $\mathrm{c}$ oxidase subunit $\mathrm{I}$ from diverse metazoan invertebrates. Mol Mar Biol Biotechnol 3 (5): 294-299.

Fakunmoju FA, Akintola SL, Ijimakinde B. 2014. Comparative Analysis of the Morphometric and Meristic Character of Lutjanidae from Lekk and Badagry Lagoons in Lagos State Nigeria. Journal of Agriculture and Veterinary Science 7 (1): 81-88

Hall TA 1999. BioEdit: a user-friendly biological sequence alignment editor and analysis program for Windows 95/98/NT. Nuc Acids Symp Ser 12: 95-98.

Holden MJ, Raitt DFS. 1974. Manual of fisheries science. Part 2-Methods of resource investigation and their application. FAO, Rome
Ikpeme EV, Ekerette EE, Udensi OU, Ozoje MO. 2017. Assessment of Morphological Variation in Wild and Cultured Populations of Tilapia Fish (Oreochromis niloticus). J Adv Biol Biotechnol 13: 1-10.

Inoue K, Takei Y. 2003. Asian medaka fishes offer new models for studying mechanisms of seawater adaptation. Comp Biochem Physiol B Biochem Mol Biol 136 (4): 635-645.

Kimura M. 1980. A simple method for estimating evolutionary rate of base substitutions through comparative studies of nucleotide sequences. J Mol Evol 16:111-120.

Kim H, Lee W, Lee S. 2010. Morphometric relationship, phylogenetic correlation, and character evolution in the species-rich genus Aphis (Hemiptera: Aphididae). PloSOne 5 (7): 1-13.

Kress WJ, Erickson DL. 2012. DNA barcodes: methods and protocols. In DNA Barcodes 3-8.

Kumar S, Stecher G, Li M, Knyaz C, Tamura K. 2018. MEGA X: molecular evolutionary genetics analysis across computing platforms. Mol Biol Evol 35 (6): 1547-1549.

Lin Y, Gao Z, Zhan A. 2015. Introduction and use of non-native species for aquaculture in China: status, risks and management solutions. Rev Aquacult 7 (1): 28-58

Liu J, Jiang J, Song S, Tornabene L, Chabarria R, Naylor G, Li C. 2017. Multilocus DNA barcoding - Species Identification with Multilocus Data. Sci Rep 7 (1): 16601 .

Mandagi IF, Mokodongan DF, Tanaka R, Yamahira K. 2018. A New Riverine Ricefish of the Genus Oryzias (Beloniformes, Adrianichthyidae) from Malili, Central Sulawesi, Indonesia. Copeia 106 (2): 297-304.

Martinez AS, Willoughby JR, and Christie MR. 2018. Genetic diversity in fishes is influenced by habitat type and life-history variation. Ecol Evol 8 (23): 12022-12031.

Marzouk Z, Chenuil A, Aurelle D, Said K. 2016. Genetic diversity and population structure of the banded Murex, Hexaplextrunculus (Linnaeus, 1758) across the Siculo-Tunisian Strait. J Res Biol Sci 2 (201): 8-12.

Magtoon W, Termvidchakorn A. 2009. A revised taxonomic account of ricefish Oryzias (Beloniformes; Adrianichthyidae), in Thailand, Indonesia and Japan. Trop Nat Hist 9 (1): 35-68.

Panprommin D, Soontornprasit K, Tuncharoen S, Pithakpol S, Keereelang J. 2019. DNA barcodes for the identification of species diversity in fish from Kwan Phayao, Thailand. J Asia-Pac Biodivers 12: 382-89.

Parenti LR. 2008. A phylogenetic analysis and taxonomic revision of ricefishes, Oryzias and relatives (Beloniformes, Adrianichthyidae). Zool J Linn Soc 154 (3): 494-610.

Parenti LR, Hadiaty, RK, Lumbantobing D, Herder F. 2013. Two new ricefishes of the Genus Oryzias (Atherinomorpha: Beloniformes: Adrianichthyidae) augment the endemic freshwater fish fauna of Southeastern Sulawesi, Indonesia. Copeia 2013 (3): 403-409.

Quilang JP, Basiao ZU, Pagulayan RC, Roderos, RR, Barrios EB. 2007. Meristic and morphometric variation in the silver perch, Leiopotherapon plumbeus (Kner, 1864), from three lakes in the Philippines. J Appl Ichthyol 23 (5): 561-567.

Seebacher F, Webster MM, James RS, Tallis J, and Ward AJW. 2016. Morphological differences between habitats are associated with physiological and behavioural trade-offs in stickleback (Gasterosteus aculeatus). R Soc Open Sci 3 (6): 160316

Shima A, Mitani H. 2004. Medaka as a research organism: past, present and future. Mech Dev 121 (7-8): 599-604

Simon KD, Bakar Y, Temple SE, Mazlan AG. 2010. Morphometric and meristic variation in two congeneric archer fishes Toxotes chatareus (Hamilton 1822) and Toxotes jaculatrix (Pallas 1767) inhabiting Malaysian coastal waters. J Zhejiang Univ Sci 11 (11): 871-879.

Takehana Y, Naruse K, Sakaizumi M. 2005. Molecular phylogeny of the medaka fish genus Oryzias (Beloniformes: Adrianichthyidae) based on nuclear and mitochondrial DNA sequences. Mol Phylogenet Evol 36 (2): 417-428

Wang JF, Jiang LY, Qiao GX. 2011. Use of a mitochondrial COI sequence to identify species of the subtribe Aphidina (Hemiptera, Aphididae). ZooKeys 122: 1-17

Wark AR, Peichel CL. 2010. Lateral line diversity among ecologically divergent threespine stickleback populations. J Exp Biol 213 (1): 108117.

Wawrowski A, Gerlach F, Hankeln T, Burmester T. 2011. Changes of globin expression in the Japanese medaka (Oryzias latipes) in response to acute and chronic hypoxia. J Comp Physiol B 181 (2): 199-208. 
Viswambharan D, Pavan-Kumar A, Singh DP, Jaiswar AK, Chakraborty SK, Nair JR, Lakra WS. 2015. DNA barcoding of gobiid fishes (Perciformes, Gobioidei). Mitochondrial DNA 26 (1): 15-19.

Yang Z. 1994. Maximum likelihood phylogenetic estimation from DNA sequences with variable rates over sites: approximate methods. J Mol Evol 39 (3): 306-314.
Zhang J, Hanner R. 2012. Molecular Approach to the Identification of Fish in the South China Sea. PLoS ONE 7 (2): e30621. DOI: 10.1371/journal.pone.0030621. 